\title{
Inhibitory and Stimulatory Effects of Some Metals on Asparaginase Activity Produced by Staphylococcus MGM1
}

\section{Mahtab Ghorbanmovahed $^{1 *}$, Gholamhossein Ebrahimipour ${ }^{1}$, Abdolrazagh Marzban $^{2}$}

1. Department of Microbiology and Microbial Biotechnology, Faculty of Life Sciences and Biotechnology, Shahid Beheshti University, Tehran, Iran

2. Razi Herbal Medicines Research Center, Lorestan University of Medical Sciences, Khorramabad, Iran

\section{ABSTRACT}

Background: Asparaginases are known to be the cornerstone for the treatment of acute lymphoblastic leukemia (ALL) and are used for treatment in all pediatric regimens as well as in the majority of adult treatment protocols. Clinical hypersensitivity reactions against commercially available asparaginase have resulted in the failure in treatment of ALL in more than $60 \%$ of cases. Thus, it is required to search for serologically different asparaginases from new organisms for patients exhibiting sensitivity to one formulation of asparaginase.

Materials \& Methods: The experiments were conducted in $250 \mathrm{~mL}$ flasks containing $100 \mathrm{~mL}$ of $\mathrm{M} 9$ broth medium and incubated at $35^{\circ} \mathrm{C}$ for $48 \mathrm{~h}$ with shaking $100 \mathrm{rpm}$. The bacterium produced an extracellular asparaginase enzyme in which a heavy metal-rich medium was influenced. Considering this idea, enzyme activity was marked at the presence of metal salts such as $\mathrm{FeCl}_{3}, \mathrm{ZnCl}_{2}, \mathrm{CoCl}_{2}, \mathrm{MgCl}_{2}, \mathrm{CaCl}_{2}, \mathrm{CuSO}_{4}, \mathrm{KCl}$ and $\mathrm{NaCl}$ with the different concentrations as $0-3 \% \mathrm{~W} / \mathrm{V}$.

Results: In this research, we isolated a bacterium belonged to staphylococcus species named strain MGM1 and deposited to $\mathrm{NCBI}$ by accession number of $\mathrm{KT} 361190$. The results showed that $\mathrm{Na}^{+}, \mathrm{Fe}^{2+}$ and $\mathrm{K}^{+}$were inducted to enzyme production and $\mathrm{Zn}^{2+}$ had no effects on enzyme activity, while $\mathrm{Cu}^{2+}, \mathrm{Ca}^{2+}$, and $\mathrm{Mg}^{2+}$ inhibited enzyme activity when their concentrations increased up to $1 \%$.

Conclusion: This study aimed to investigate the effects of different ions on the activity of the enzyme in the blood and fluid of the body. Such compounds are vital elements in the blood and therefore, their effect on the enzyme is very important So This experiment suggests that asparaginase could be affected by the metals.

Keywords: Antileukemia activity, Heavy metal, Inhibitory effect, L-asparaginase, Stimulatory effect, Staphylococcus

Received: 2019/12/04; Accepted: 2019/12/30; Published Online: 2020/01/10

\begin{tabular}{|c|c|}
\hline Corresponding Information: & $\begin{array}{l}\text { Mahtab Ghorbanmovahed, Department of Microbiology, Faculty of Medicine, Iran University of Medical Sciences, Tehran, Iran. } \\
\text { Email: } \underline{\text { mghorbanmovahed@gmail.com }}\end{array}$ \\
\hline (c) (1) (9) & $\begin{array}{l}\text { This is an original open-access article distributed under the terms of the Creative Commons Attribution-noncommercial } 4.0 \text { International License which } \\
\text { edistribution of the material just in noncommercial usages with proper citation. }\end{array}$ \\
\hline
\end{tabular}

Use your device to scan and read the article online

Ghorbanmovahed M, Ebrahimipour G, Marzban A. Inhibitory and Stimulatory Effects of Some Metals on Asparaginase Activity Produced by Staphylococcus MGM1. Iran J Med Microbiol. 2019; 13 (5):374378

Download citation: BibTeX | RIS | EndNote | Medlars | ProCite | Reference Manager | RefWorks
Send citation to:
8 Mendeley
2 Zotero
Hit RefWorks

\section{Introduction}

L-asparaginase is a well-known enzyme acting on neoplastic cell diseases, especially acute lymphoblastic leukemia (ALL), therefore, it can inhibit their growth in the blood circulatory system (1) L-asparaginase activity leads to hydrolysis of L-asparagine into aspartic acid and ammonium. This enzyme plays a crucial role as a promising agent in the current treatment methods of cancer therapy, through removing asparagines that thus, could cause to inhibit the growth of tumor cells $(2,3) \mathrm{L}$ asparaginase is used as an efficient antitumor drug and has been obtained either from Escherichia coli or Erwinia caratovora $(4,5)$. Therefore, $L$ asparaginase originated from bacterial species had been considered as the main source for clinical applications $(6,7)$. 
However, it is found out that bacteria producing Lasparaginase might be affected by various factors in environments (8). Heavy metals are known as effective factors on the metabolism and growth of bacteria $(9,10)$. Herein, L-asparaginase activity in presence of some metal ions, was studied as it has never been reported in in-vivo studies (11). This research focuses on various metal salts implemented for the production of Lasparaginase in broth media. Thus, the work aims to give an overview of the microbial production of Lasparaginase at the presence of some heavy metals.

\section{Materials and Methods}

Soil samples were collected from several different places at a surface of farmlands around the Gharchak regions in November, Tehran, Iran. The samples were collected in sterile plastic bags and carried to the laboratory for microbial isolation. The preliminary screening was performed on nutrient agar plates. Then, the bacterial isolate showing asparaginase activity was detected on M9 modified agar plates supplemented with $0.500 \mathrm{~mL}$ of $1 \%$ phenol red as $\mathrm{pH}$ indicator that changed its color when the isolates catalyzed L-asparagine to $\mathrm{L}$ aspartic acid and ammonia $(12,13)$.

The identification of the bacterial isolates was first identified through biochemical experiments and morphological characteristics based on macroscopic and microscopic observation. All the experiments were performed according to Bergey's manual of determinative bacteriology (14). Phylogenetic analysis was done using 16S rDNA sequencing based on comparing with closest spices deposited in NCBI through Blast alignment software.

\section{Optimization of Enzyme Production}

To study enzyme activity in selected bacterium, a synthetic broth medium was designed. M9 medium agar contain asparagus as a nitrogen source, glucose as carbon and $\mathrm{K}_{2} \mathrm{HPO}_{4}$ as phosphate sources. Some microelements were also added to the medium to be found vital for growth and enzyme production by bacteria. Initial culture conditions were as follows: $\mathrm{pH}=7$, temperature $30^{\circ} \mathrm{C}$, shaking speed $100 \mathrm{rpm}$ and time incubation $48 \mathrm{~h}$. Optimization of culture conditions was performed by the different physical and nutritional factors, such as initial $\mathrm{pH}(5-10)$, temperature $\left(20-40^{\circ} \mathrm{C}\right)$, agitation speed $(80,90,100,110,120,130 \mathrm{rpm})$, carbon sources (glucose, sucrose, fructose, starch, and lactose) and nitrogen sources (yeast extract, beef extract, malt extract, peptone, L-asparagine, L-glutamine and tryptone). All experiments were performed in Erlenmeyer $250 \mathrm{~mL}$ containing $100 \mathrm{~mL}$ of broth medium as triple replications.

\section{Enzyme Activity Assay}

L-Asparaginase enzyme assay was done through the calorimetric method in terms of liberated ammonia from asparaginase activity using Nessler's reagent (15). After $48 \mathrm{~h}$ of incubation, the bacterial cells were removed by centrifuging the culture broth at 7,800 $\times g$ for $15 \mathrm{~min}$ and the cell-free extract $(0.2 \mathrm{~mL})$ was mixed with $0.8 \mathrm{~mL}$ of 0.05 Molar Tris-HCl buffer. Subsequently, $1 \mathrm{~mL}$ of 0.04 Molar L-asparagine was added to the mixture and the reaction mixture was incubated for $15 \mathrm{~min}$ at $37^{\circ} \mathrm{C}$ in a water bath shaker. Finally, the reaction was stopped using $0.5 \mathrm{~mL}$ of $15 \%(\mathrm{w} / \mathrm{v})$ trichloroacetic acid (TCA) and the produced ammonia from the enzymatic reaction was measured spectrometrically using Nessler's reagent at an absorbance wavelength of $500 \mathrm{~nm}$.

The enzyme activity was extrapolated from the liberated ammonia based on a standard curve of ammonium sulfate. The one I.U. (International Unit) of $\mathrm{L}$-asparaginase is equal to one $\mu \mathrm{mol}$ of ammonia released from $\mathrm{L}$-asparagine per minute.

Enzyme activity treated by heavy metal ions was studied. The influence of metal ions such as $\mathrm{K}+, \mathrm{Na}+$, $\mathrm{Zn} 2+, \mathrm{Cu} 2+, \mathrm{Ca} 2+, \mathrm{Mg}^{2+}, \mathrm{Co}^{2+}$, and $\mathrm{Fe}^{2+}$ was studied in different concentrations (0-3\%). After $48 \mathrm{~h}$ of incubation at $37^{\circ} \mathrm{C}$, inhibitory or stimulatory of the metals were determined for enzyme activity and growth rate of the bacterium.

\section{Results}

\section{Isolation and Identification of the Bacterium}

Among 75 isolates, only 4 bacterial colonies showed potential L-asparaginase activity. The one that had the most halo red zones on $\mathrm{M} 9$ agar was selected for further studies. Figure 1 showes the bacteria with asparaginase activity that changed the $\mathrm{pH}$ of the medium when asparaginase released ammonia and diffused vicinity of the colonies.

\section{Identification of Strain MGM1}

The phylogenetic analysis demonstrated $97 \%$ similarity to 31 Staphylococcus sp, $97 \%$ similarity to 33 species of Staphylococcus warneri and $97 \%$ similarity to 18 species of Staphylococcus pasteuri. Based on the physicochemical properties and the 16S rDNA sequence, this bacterium belongs to the Staphylococcus genus and designated as Staphylococcus sp. MGM1. The phylogenetic tree (Figure 2) placed the MGM1 strain clearly in distinct branches among the Staphylococcus genus.

\section{Optimization of Enzyme Production}

The results of the optimization experiment indicated the desirable physical conditions of each factor as $\mathrm{pH}=8$, temperature $37^{\circ} \mathrm{C}$, shaking $100 \mathrm{rpm}$. To optimize the bacterial growth in synthetic medium, nutritional factors 
were glucose (as a carbon source), beef extract (as nitrogen source) and $\mathrm{K}_{2} \mathrm{H} \mathrm{PO}_{4}$ (as phosphate source).

\section{Effect of Heavy Metals on Asparaginase Activity}

The results of asparaginase activity at the presence of 8 metal salts showed that $\mathrm{Na}^{+}, \mathrm{Fe}^{2+}$, and $\mathrm{K}^{+}$had a positive effect at $0.5,0.5$ and $1 \%$, respectively while $\mathrm{Zn}^{2+}$ and $\mathrm{Mg}^{2+}$ showed no effect on asparaginase activity. Herein, $\mathrm{Cu}^{2+}$, $\mathrm{Ca}^{2+}$, and $\mathrm{Mg}^{2+}$ had a negative effect up to $1 \%$ of their concentration. $\mathrm{Co}^{2+}$ with more than $0.5 \% \mathrm{w} / \mathrm{v}$ was also shown an inhibitory effect.

Table 1. Identification results of isolates based on blast morphology and search and their access number registered in the gene bank
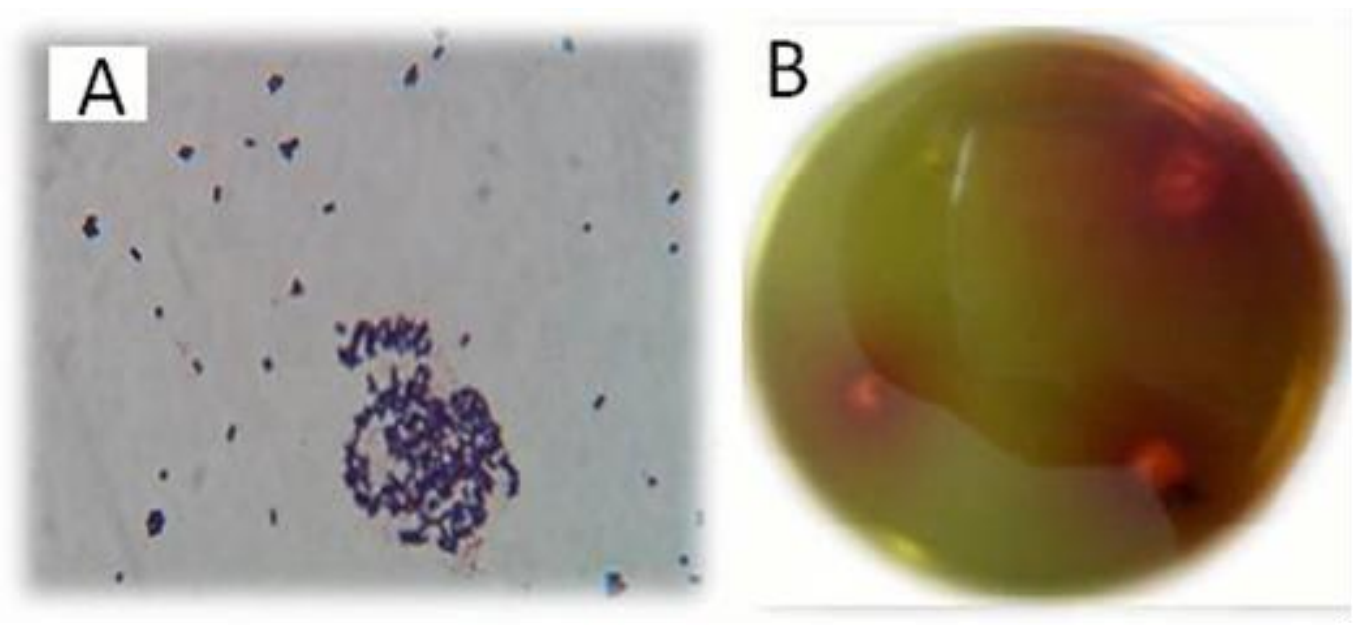

Figure 1. The isolated bacterium graphs. A) gram staining photo and B) asparaginase producing colonies on an $\mathrm{M} 9$ agar plate that the color of agar has changed due to the production of ammonia and created a red color around their colonies.

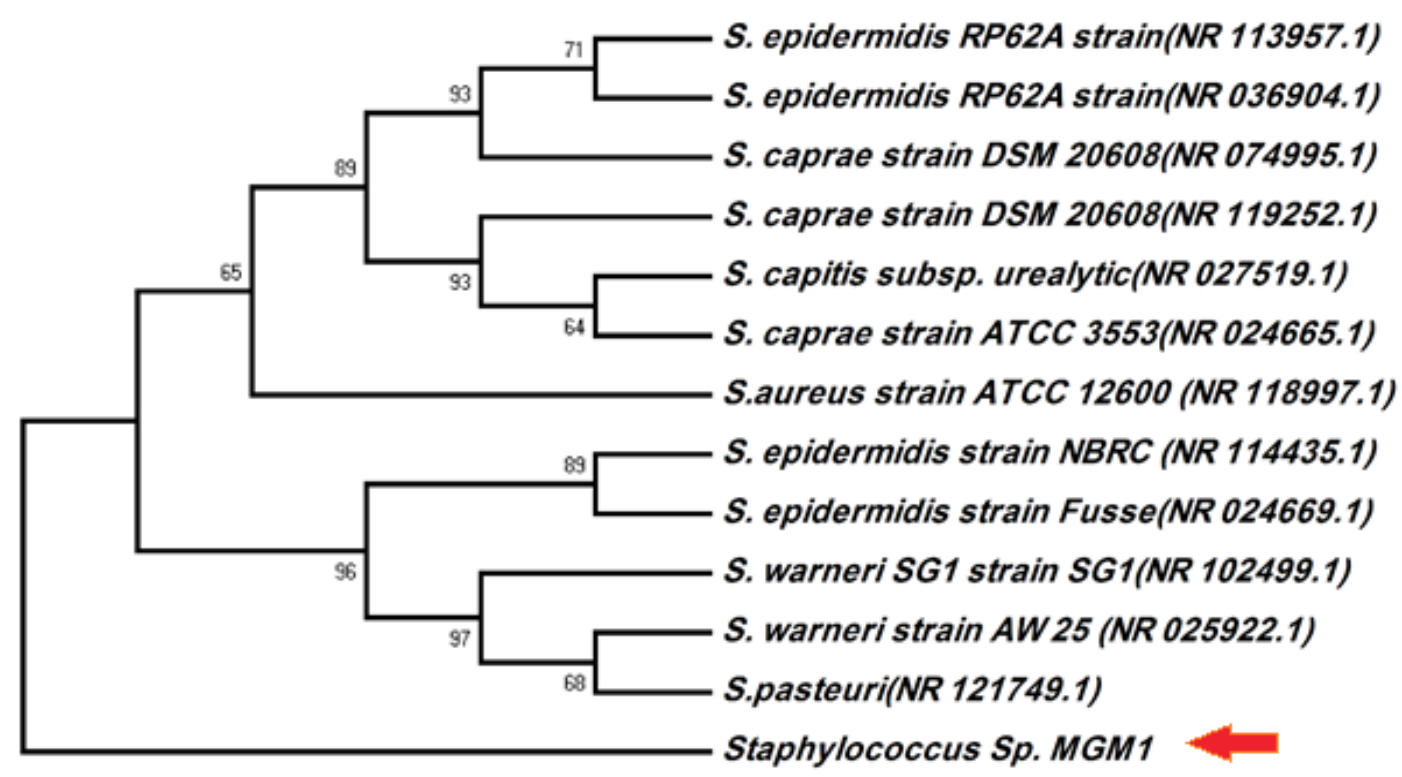

Figure 2. The phylogenetic relationship of Staphylococcus sp. 

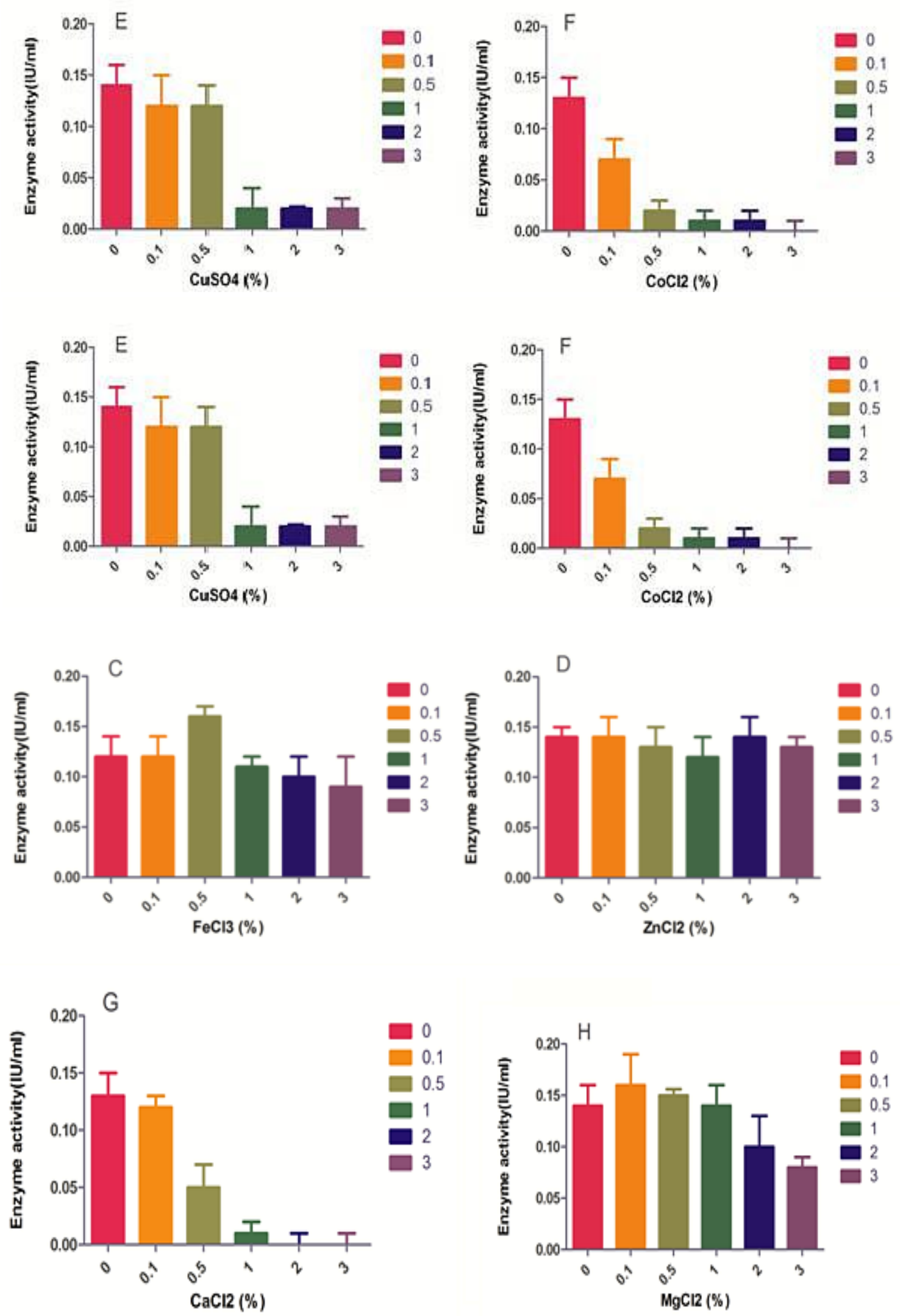

Figure 3. The effect of metal salts on asparaginase activity in the medium after $48 \mathrm{~h}$ incubation at $37^{\circ} \mathrm{C}$ with agitation speed $100 \mathrm{rpm}$. 


\section{Discussion}

Homology greater than $99 \%$ and conformity of the studied bacteria with the suggested bacteria indicates species identification. Homologs of $97 \%$ to less than $99 \%$ are identified by genus. Homology of $93 \%$ to less than $97 \%$ indicates a new species or genus, and homology below 93\% usually represents a new genus and requires further information to confirm it. Our study reported that MGM1 isolate produced an asparaginase enzyme that is sensitive to metal concentration in the medium. Of course, it must be optimized with salt composition during the fermentation process.

The influence of metals on enzyme activity has already been in line with many authors' ideas. For example, Mase et al., (1995) reported that lipase activity is not affected by $\mathrm{Ca}^{2+}, \mathrm{Mg}^{2+}, \mathrm{Mn}^{2+}, \mathrm{Na}^{+}, \mathrm{K}^{+}$, and $\mathrm{Cu}^{2+}$ in Penicillium roqueforti (16). A. Jayaprakash and $\mathrm{P}$. Ebenezer (2012) reported that Calcium chloride appeared to be the best inducer of lipase yielding as much as $100 \%$ relative activity followed by mercuric chloride, magnesium chloride and barium chloride (17).

The results showed that $\mathrm{Co}$ and $\mathrm{Cu}$ repressed enzyme production, which is in accordance with the results of Shora and Ali (2013) showing that $\mathrm{Na}^{+}, \mathrm{Zn}^{2+}$, and $\mathrm{Cu}^{2+}$ act as inhibitory for L-asparaginase (18). In contrast, Basha et al. showed stimulatory effect for $\mathrm{Mg}^{2+}$ and inhibitory for $\mathrm{Zn}^{2+}$ on asparaginase isolated from actinomycetes, while our enzyme showed little effect for $\mathrm{Mg}^{2+}$ and no effect for $\mathrm{Zn}^{2+}$ (19). Different ions have different effects on enzymatic activity. This study aimed to investigate the effects of different ions on the activity of the enzyme in the blood and fluid of the body, which affects enzymatic activity. Such compounds are vital elements in the blood and therefore, their effect on the enzyme is very important.

\section{Conclusion}

According to the homology and physiological percentages of the bacterium in this study, it is probably a new species of Staphylococcus genus or a strain of Staphylococcus warneri or Staphylococcus pasteuri. And recorded as Staphylococcus sp. MGM1 under the accession number KT361190. The research showed the enzymatic activity of L-asparaginase like other enzymes could be influenced by the various factors. This matter is a critical issue for enzyme reactions, especially, in the case of this study, that the enzyme was admitted as an intravenous drug and contacts with blood components such as cells, ions, proteins, etc. Therefore, it is necessary that enzyme activity be evaluated while being treated by various factors.

\section{Acknowledgment}

The authors thank everyone who helped them with this research.

\section{Conflict of Interest}

Authors declared no conflict of interests.

\section{References}

1. Ramya LN, Doble M, Rekha VPB, Pulicherla KK \%J A biochemistry, biotechnology. L-Asparaginase is a potent anti-leukemic agent and its significance in having reduced glutaminase side activity for better treatment of acute lymphoblastic leukemia. 2012;167(8):2144-59. [DOI:10.1007/s12010-0129755-z] [PMID]

2. Kumar S, Stecher G, Li M, Knyaz C, Tamura K \%J M biology, evolution. MEGA $\mathrm{X}$ : molecular evolutionary genetics analysis across computing platforms. 2018;35(6):1547-9. [DOI:10.1093/molbev/msy096] [PMID] [PMCID]

3. Verma N, Kumar K, Kaur G, Anand S \%J C reviews in biotechnology. L-asparaginase: a promising chemotherapeutic agent. 2007;27(1):45-62. [DOI:10.1080/07388550601173926] [PMID]

4. Ghoshoon MB, Raee MJ \%J AJBB. An optimized medium for the screening of L-asparaginase production by Escherichia coli. 2008;4(4):422-4. [DOI:10.3844/ajbbsp.2008.422.424]

5. Duval M, Suciu S, Ferster A, Rialland X, Nelken B, Lutz $P$, et al. Comparison of Escherichia coliasparaginase with Erwinia-asparaginase in the treatment of childhood lymphoid malignancies: results of a randomized European Organisation for Research and Treatment of Cancer-Children's Leukemia Group phase 3 trial. 2002;99(8):2734-9. [DOI:10.1182/blood.V99.8.2734] [PMID]

6. Peterson RE, Ciegler A \%J A microbiology. Lasparaginase production by various bacteria. 1969;17(6):929. [DOI:10.1128/AEM.17.6.929930.1969] [PMID] [PMCID]

7. Vellard $M$ \% $\mathrm{C}$ opinion in biotechnology. The enzyme as a drug: application of enzymes as pharmaceuticals. 2003;14(4):444-50. [DOI:10.1016/S0958-1669(03)00092-2]

8. Deng SP, Tabatabai MA \%J S biology, biochemistry. Cellulase activity of soils: effect of trace elements. 1995;27(7):977-9. 0717(95)00005-Y]

9. Shrivastava A, Khan AA, Khurshid M, Kalam MA, Jain SK, Singhal PK \%J $C$ reviews in 
oncology/hematology. Recent developments in the I-asparaginase discovery and its potential as anticancer agents. 2016; 100:1-10. [DOI:10.1016/j.critrevonc.2015.01.002] [PMID]

10. Raha SK, Roy SK, Dey SK, Chakrabarty SL \%J B international. Purification and properties of an Lasparaginase from Cylindrocarpon obtusisporum MB-10. 1990;21(6):987-1000.

11. Ashok A, Doriya K, Rao JV, Qureshi A, Tiwari AK, Kumar DS \%J $S$ reports. Microbes producing LAsparaginase free of Glutaminase and Urease isolated from extreme Locations of Antarctic soil and Moss. 2019;9(1):1423. [DOI:10.1038/s41598018-38094-1] [PMID] [PMCID]

12. Egler RA, Ahuja SP, Matloub $Y \% J$ J of pharmacology, pharmacotherapeutics. Lasparaginase in the treatment of patients with acute lymphoblastic leukemia. 2016;7(2):62. [DOI:10.4103/0976-500X.184769] [PMID] [PMCID]

13. Upadhyay R, Saxena A, Kango N. Screening and production of tumour inhibitory L-asparaginase by bacteria isolated from soil. Asian J Pharm Clin Res. 2012;5:135-7.

14. "Bergey's Manual of Determinative Bacteriology (5th ed.)." American Journal of Public Health and the Nations Health, 29(4), pp. 404-405 [DOI:10.2105/AJPH.29.4.404] [PMCID]
15. Joner $P E$, Kristiansen $T$, Einarsson $M \% J$ et $B A-E$. Purification and properties of L-asparaginase $A$ from Acinetobacter calcoaceticus. 1973;327(1):146-56. [DOI:10.1016/00052744(73)90112-5]

16. Mase T, Matsumiya $Y$, Akiba biotechnology, $T \% J$, biochemistry. Purification and characterization of a new lipase from Fusarium sp. YM-30. 1995;59(9):1771-2. [DOI:10.1271/bbb.59.1771] [PMID]

17. Jayaprakash A, Ebenezer P. Purification and characterization of Aspergillus japonicus lipase from a pig fat production medium. Journal of Academia and Industrial Research. 2012 Jun;1(1):1-7.18. El-Shora HE, Ali AS. Enhancement the activity of L-asparaginase and antioxidant enzymes in Cicer arietium L cotyledons under stress conditions. International Journal of Agronomy and Plant Production. 2013;4(Special Issue):3724-35.

18. Basha NS, Rekha R, Komala M, Ruby S. Production of Extracellular Anti-leukaemic Enzyme Lasparaginase from Marine Actinomycetes by Solidstate and Submerged Fermentation: Purification and Characterisation. Trop J Pharm Res. 2009;8(4). [DOI:10.4314/tjpr.v8i4.45230] 